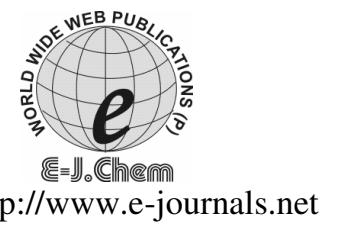

ISSN: 0973-4945; CODEN ECJHAO

E-Journal of Chemistry 2010, 7(1), 180-184

\title{
Simultaneous Determination of Lamivudine, Zidovudine and Abacavir in Tablet Dosage Forms by RP HPLC Method
}

\author{
D. ANANTHA KUMAR, G. SRINIVASA RAO \\ and J.V.L.N. SESHAGIRI RAO* \\ "Pharmaceutical Analysis and Quality Assurance Division, \\ A. U. College of Pharmaceutical Sciences, \\ Andhra University, Visakhapatnam-530 003, India. \\ jvlns@yahoo.com
}

Received 14 July 2009; Accepted 28 August 2009

\begin{abstract}
A simple, accurate and reproducible RP-HPLC method has been developed for the simultaneous determination of lamivudine, zidovudine and abacavir in tablet dosage forms. Chromatography was carried out on a HiQ Sil C $18 \mathrm{~V}$ column using a mobile phase consisting of $0.01 \mathrm{M}$ potassium dihydrogen ortho-phosphate $(\mathrm{pH} 3.0)$ and methanol $(55: 45 \mathrm{v} / \mathrm{v})$ at a flow rate of $0.8 \mathrm{~mL} / \mathrm{min}$. The detection was made at $272 \mathrm{~nm}$ and stavudine was used as the internal standard for this study. The retention times for lamivudine, abacavir and zidovudine were found to be $3.8,6.3,8.1 \mathrm{~min}$. respectively. The calibration curves were linear over the range $5-250 \mu \mathrm{g} / \mathrm{mL}$ for both zidovudine and abacavir and 5-140 $\mu \mathrm{g} / \mathrm{mL}$ for lamivudine. The proposed method was validated as per ICH and USP guidelines and it was found suitable for the routine quality control analysis of the drugs in tablet dosage forms.
\end{abstract}

Keywords: Lamivudine, Zidovudine, Abacavir, RP- HPLC, Tablets.

\section{Introduction}

Antiretroviral drugs like nucleoside reverse transcriptase inhibitors, non nucleoside reverse transcriptase inhibitors, and protease inhibitors are essential in the management of HIV infection. The synthetic nucleoside reverse transcriptase inhibitor analogues abacavir, lamivudine and zidovudine form one of the fixed dosage combinations used in the effective management of $\mathrm{HIV}^{1-2}$. Abacavir, chemically known as [(1R)-4-[2-amino-6-(cyclopropylamino)-9H-purin-9yl \}-2-cyclopentene]-1-methanol, is a carbocyclic synthetic analogue. Its active metabolite carbovir triphosphate, an analogue of deoxyguanosine-5' -triphosphate (d GTP), inhibits the activity of HIV-1 reverse transcriptase both by competing with the natural substrate dGTP 
and by its incorporation into viral DNA. The active triphosphate metabolites zidovudine (3azido-3-deoxythymidine) and lamivudine (4-amino-1-((2R,5S-2-(hydroxymethyl)-1,3oxathiolan-5-yl) pyrimidin-2-(1H)-one) act against HIV by inhibition of reverse transcriptase via DNA chain termination after incorporation of the nucleotide analogue. A literature survey reveals the report of a few analytical methods for the determination of these drugs individually in serum samples and in their dosage forms. Methods for the simultaneous determination of lamivudine and zidovudine in biological samples and in pharmaceutical preparations were also reported ${ }^{3-6}$. A reported method for the determination of the lamivudine, zidovudine and abacavir in tablets, human serum and in drug dissolution studies employs a complex buffer system (methanol, water, phosphate buffer) ${ }^{7}$. The authors now propose a simple, precise and accurate method for the simultaneous determination of lamivudine, ziduvudine and abacavir in tablet dosage forms employing a mobile phase consisting of $0.01 \mathrm{M}$ potassium dihydrogen ortho-phosphate $(\mathrm{pH} 3.0$ ) and methanol to achieve good peak shapes with appreciable resolution.

\section{Experimental}

\section{Chromatographic conditions}

A Jasco HPLC instrument equipped with a HiQ Sil C18 V analytical column (250 X $4.6 \mathrm{~mm}$; $5 \mu$ ), a PU 2080 pump, a Rheodyne 7125 sample injector with a $20 \mu \mathrm{L}$ loop and a UV-2075 detector was employed for this analysis.

A mobile phase consisting of a mixture of $0.01 \mathrm{M}$ potassium dihydrogen orthophosphate (PH 3.0) and methanol in a ratio of 45:55 (v/v) was prepared and filtered through a $0.45 \mu$ membrane filter and degassed by helium sparging before use.

\section{Drug samples}

Reference standard samples of abacavir, zidovudine and lamivudine and internal standard stavudine were procured from Aurobindo Pharma Ltd., Hyderabad. A commercial sample trizivir tablets (Glaxo-smithkline) containing zidovudine $(300 \mathrm{mg})$, lamivudine $(150 \mathrm{mg})$ and abacavir (300 $\mathrm{mg}$ ) were purchased from local market.

\section{Drug and internal standard solutions}

Stock solutions of lamivudine, zidovudine and abacavir were prepared by dissolving $25 \mathrm{mg}$ of each drug in separate $25 \mathrm{~mL}$ volumetric flasks in methanol with sonication for about 15 min. From the individual stock solutions working standard solutions were prepared in a concentration range of $5-300 \mu \mathrm{g} / \mathrm{mL}$ for both zidovudine and abacavir and $5-200 \mu \mathrm{g} / \mathrm{mL}$ for lamivudine.

A stock solution of internal standard, stavudine, was prepared by dissolving $25 \mathrm{mg}$ of the drug in a $25 \mathrm{~mL}$ volumetric flask in methanol with sonication for about $15 \mathrm{~min}$. From this a working standard solution of $20 \mu \mathrm{g} / \mathrm{mL}$ was prepared with mobile phase.

\section{Calibration curve}

Separate standard calibration curves were constructed for each drug. Different volumes of stock solutions were accurately transferred into $10 \mathrm{~mL}$ volumetric flasks to prepare 5-300 $\mu \mathrm{g} / \mathrm{mL}$ concentration range for each component. Six replicate solutions in the above range were prepared for each concentration. Suitable aliquot of internal standard solution was added to get a final concentration of $20 \mu \mathrm{g} / \mathrm{mL}$ in all solutions. The calibration lines were constructed by plotting the analyte to internal standard peak area ratio against the concentration. The linear regression parameters of each drug are presented in Table 1. The results are highly reproducible with a correlation coefficient greater than 0.998 . 
Table 1. Regression characteristics of the proposed HPLC method

\begin{tabular}{lccc}
\hline Parameter & Lamivudine & Zidovudine & Abacavir \\
\hline Range, $\mu \mathrm{g} / \mathrm{mL}$ & $5-140$ & $5-250$ & $5-250$ \\
Regression equation & $\mathrm{y}=0.011 \mathrm{x}+0.031$ & $\mathrm{y}=0.006 \mathrm{x}+0055$ & $\mathrm{y}=0.006 \mathrm{x}+0.046$ \\
Correlation coefficient $\left(\mathrm{r}^{2}\right)$ & 0.9991 & 0.9989 & 0.9983 \\
\hline
\end{tabular}

Estimation of the drugs from tablet dosage forms

Ten tablets of trizivir, containing $300 \mathrm{mg}$ each of abacavir and zidovudine and $150 \mathrm{mg}$ of lamivudine were weighed and finely powdered. A quantity of the powder equivalent to one tablet content was accurately weighed, transferred into a $100 \mathrm{~mL}$ volumetric flask and dissolved in the mobile phase by sonication for about $15 \mathrm{~min}$. This solution was filtered through a $0.45 \mu$ filter paper. From the filtrate different aliquots were taken in separate 10 $\mathrm{mL}$ volumetric flasks. These solutions were spiked with a suitable volume of the internal standard solution, such that the concentration of the internal standard in each solution was $20 \mu \mathrm{g} / \mathrm{mL}$. The contents of the flasks were made up to the volume with mobile phase and mixed well. Each of these solutions $(20 \mu \mathrm{L})$ was then injected five times into the column. The mean peak area ratios of the drug to the internal standard of five such determinations for each drug were calculated and the drug contents in the tablets were quantified using the respective regression equations obtained for the reference samples.

\section{Results and Discussion}

The present study was carried out to develop a sensitive, precise and accurate HPLC method for the simultaneous determination of lamivudine, zidovudine and abacavir in pharmaceutical dosage forms. In order to effect analysis of the component peaks under isocratic conditions, mixtures of methanol with potassium dihydrogen ortho-phosphate buffer in different combinations were tested as mobile phase on a Hi Q Sil $\mathrm{C}_{18}$ stationary phase. A binary mixture of methanol and $0.01 \mathrm{M}$ potassium dihydrogen ortho-phosphate $(\mathrm{pH} 3.0)$ in a ratio of 70:30 (v/v) was proved to be the most suitable of all the combinations since the chromatographic peaks obtained were better defined and resolved and almost free from tailing. The retention times obtained for lamivudine, abacavir, zidovudine and the stavudine (internal standard) were 3.8, 6.3, 8.1 and 4.6 respectively. A Typical chromatogram showing the separation is given in Figure 1.

The method was validated by determining the linearity, sensitivity, precision and accuracy for each analyte. Six point calibration curve constructed with the working standard dilutions was found to be linear $\left(r^{2}>0.998\right)$ for each of the analytes in the concentration range of $5-250 \mu \mathrm{g} / \mathrm{mL}$ for zidovudine and abacavir sulphate and in a range of $5-140 \mu \mathrm{g} / \mathrm{mL}$ for lamivudine. The results are presented in Table 1.

Both precision and accuracy were determined with standard quality control samples prepared in triplicates at different concentration levels covering the linearity range. The repeatability and reproducibility are reported as \% RSD in Table 2 and minimum variation in the \% RSD indicate the present method is precise.

The accuracy of the proposed method was assessed by adding known amount $(25,50$ and $75 \mu \mathrm{g} / \mathrm{mL}$ ) of the drug to a drug solution of known concentration and subjecting the samples to the proposed HPLC method. All solutions were prepared and analysed in triplicate. The above procedure is adopted for all the three drugs and a high recovery values obtained (Table 3 ) indicate that the proposed method is highly accurate. 


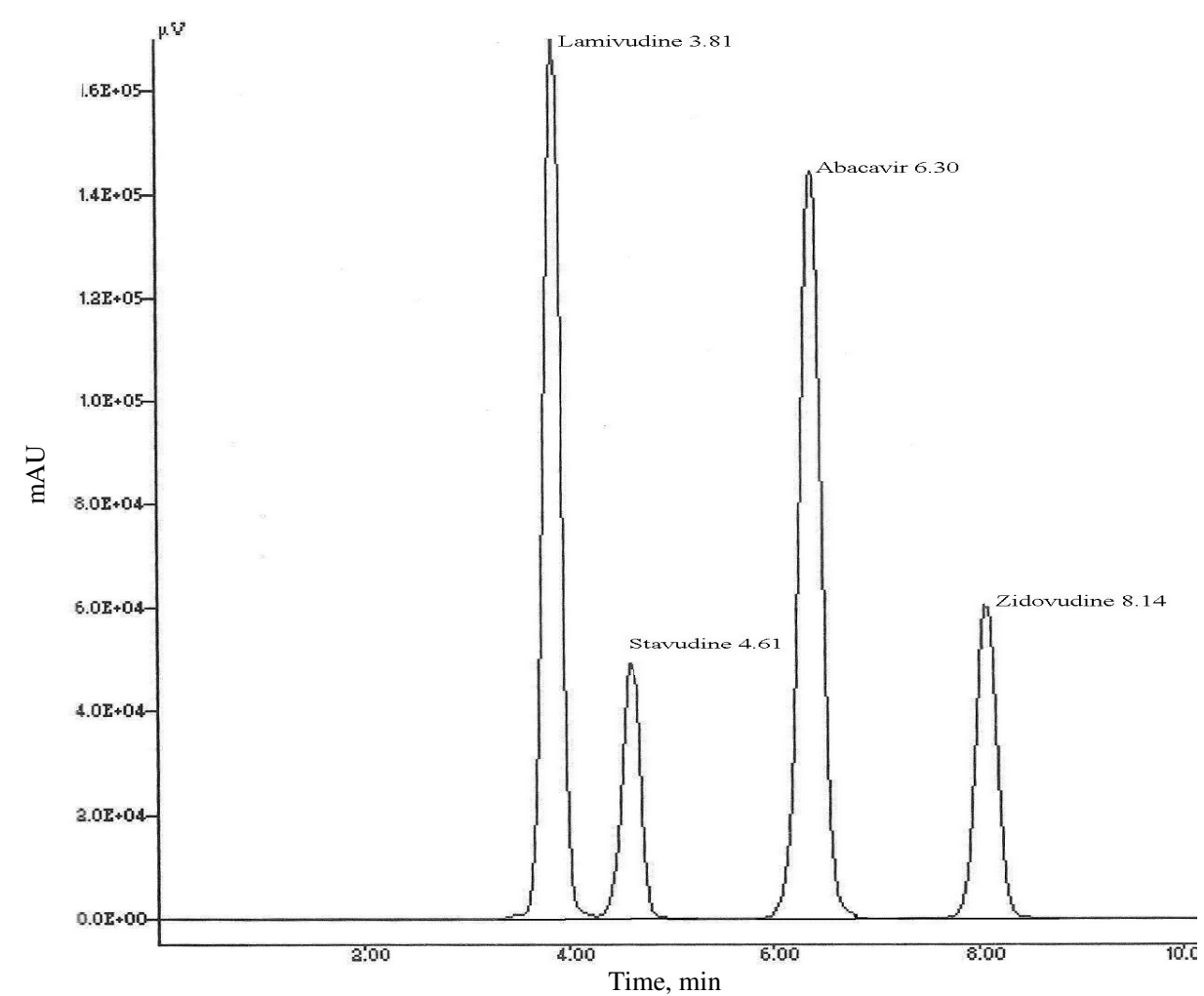

Figure 1. Typical chromatogram for the separation of lamivudine, zidovudine and abacavir with internal standard stavudine

Table 2. Precision of the proposed method.

\begin{tabular}{cccccccc}
\hline \multirow{3}{*}{ Precision } & $\begin{array}{c}\text { Drug } \\
\text { Conc } \\
\end{array}$ & \multicolumn{2}{c}{ Lamivudine } & \multicolumn{2}{c}{ Zidovudine } & \multicolumn{2}{c}{ Abacavir } \\
\cline { 3 - 8 } & $\mu \mathrm{g} / \mathrm{mL}$ & $\begin{array}{c}\text { Measured } \\
\text { conc. } \pm \text { S.D } \\
\mu \mathrm{g} / \mathrm{mL}\end{array}$ & $\begin{array}{c}\% \\
\text { RSD }\end{array}$ & $\begin{array}{c}\text { Measured } \\
\text { conc. } \pm \text { S.D } \\
\mu \mathrm{g} / \mathrm{mL}\end{array}$ & $\begin{array}{c}\% \\
\text { RSD }\end{array}$ & $\begin{array}{c}\text { Measured } \\
\text { conc. } \pm \text { S.D } \\
\mu \mathrm{g} / \mathrm{mL}\end{array}$ & $\begin{array}{c}\% \\
\text { RSD }\end{array}$ \\
\hline \multirow{3}{*}{ Intraday } & 35 & $34.97 \pm 0.17$ & 0.48 & $35.02 \pm 0.13$ & 0.37 & $34.96 \pm 0.32$ & 0.91 \\
& 80 & $80.06 \pm 0.32$ & 0.39 & $80.21 \pm 0.62$ & 0.77 & $80.31 \pm 0.55$ & 0.68 \\
& 125 & $124.88 \pm 0.53$ & 0.42 & $125.12 \pm 0.34$ & 0.27 & $125.10 \pm 0.25$ & 0.20 \\
\hline Inter-day & 35 & $35.07 \pm 0.11$ & 0.31 & $34.98 \pm 0.11$ & 0.31 & $35.02 \pm 0.32$ & 0.91 \\
& 80 & $80.12 \pm 0.69$ & 0.86 & $80.27 \pm 0.23$ & 0.29 & $80.32 \pm 0.46$ & 0.57 \\
& 125 & $125.03 \pm 0.32$ & 0.26 & $124.92 \pm 0.34$ & 0.27 & $125.18 \pm 0.63$ & 0.50 \\
\hline
\end{tabular}

Table 3. Recoveries of drugs by the proposed HPLC method

\begin{tabular}{ccccccc}
\hline \multirow{2}{*}{$\begin{array}{c}\text { Amount } \\
\text { of drug } \\
\text { added }\end{array}$} & \multicolumn{2}{c}{ Lamivudine } & \multicolumn{2}{c}{ Zidovudine } & \multicolumn{2}{c}{ Abacavir } \\
\cline { 2 - 7 }$\mu \mathrm{g} / \mathrm{mL}$ & $\begin{array}{c}\text { Amount } \\
\text { recoverd } \pm \text { S.D. } \\
\mu \mathrm{g} / \mathrm{mL}\end{array}$ & $\begin{array}{c}\% \\
\text { RSD }\end{array}$ & $\begin{array}{c}\text { Amount } \\
\text { recoverd } \pm \text { S.D } \\
\mu \mathrm{g} / \mathrm{mL}\end{array}$ & $\begin{array}{c}\% \\
\text { RSD }\end{array}$ & $\begin{array}{c}\text { Amount } \\
\text { recoverd } \pm \text { S.D } \\
\mu \mathrm{g} / \mathrm{mL}\end{array}$ & $\begin{array}{c}\% \\
\text { RSD }\end{array}$ \\
\hline 25 & $24.97 \pm 0.17$ & 0.68 & $25.02 \pm 0.13$ & 0.51 & $34.96 \pm 0.32$ & 0.91 \\
50 & $50.06 \pm 0.32$ & 0.63 & $49.90 \pm 0.32$ & 0.64 & $51.01 \pm 0.25$ & 0.49 \\
125 & $124.88 \pm 0.53$ & 0.42 & $125.12 \pm 0.34$ & 0.27 & $125.10 \pm 0.25$ & 0.20 \\
\hline
\end{tabular}


The recovery values of the three drugs from the tablet dosage forms by the developed method range from 99.4 to 100.4 percent (Table 4). The method specificity was assessed by studying the chromatograms obtained from a mixture of the drugs and the common excipients. The method was found to be specific as none of the excipients interfered with the analytes of interest. Hence, the method was found to be suitable for analysing the commercial antiretroviral formulations.

System suitability parameters were studied with six replicates of standard sample solutions and the parameters are presented in Table 5.

Table 4. Recoveries of lamivudine, zidovudine and abacavir in commericial formulation by proposed HPLC method

\begin{tabular}{lcccc}
\hline $\begin{array}{c}\text { Trizivir } \\
\text { tablets }\end{array}$ & $\begin{array}{c}\text { Labeled } \\
\text { amount, mg }\end{array}$ & $\begin{array}{c}\text { Mean } \pm \text { S.D. } \\
\text { Amount recovered, mg }\end{array}$ & $\begin{array}{c}\text { Mean } \pm \text { S.D. } \\
\text { Percent recovered, mg }\end{array}$ & $\%$ RSD \\
\hline Lamivudine & 150 & $149.35 \pm 0.20$ & $99.56 \pm 0.32$ & 0.32 \\
Zidovudine & 300 & $301.25 \pm 0.32$ & $100.41 \pm 0.54$ & 0.54 \\
Abacavir & 300 & $298.34 \pm 0.15$ & $99.44 \pm 0.48$ & 0.48 \\
\hline
\end{tabular}

Table 5. System suitability parameters of lamivudine, zidovudine and abacavir.

\begin{tabular}{lccc}
\hline \multirow{2}{*}{ Parameter } & \multicolumn{3}{c}{ Value } \\
\cline { 2 - 4 } & Lamivudine & Zidovudine & Abacavir \\
\hline Retention time & 3.850 & 1.26 & 4.39 \\
Resolution & 4 & 5 & 6 \\
Capacity factor & 2.47 & 6.14 & 4.6 \\
Theoritical plates & 2978 & 8652 & 5337 \\
HETP & 0.0083 & 0.0028 & 0.0046 \\
Peak Symmetry & 1 & 1 & 1 \\
\hline
\end{tabular}

\section{Conclusion}

The proposed RP HPLC method is rapid, precise and accurate and can be used for the routine quality control analysis for the simultaneous determination of the above drugs in their tablet dosage forms.

\section{Acknowledgements}

The authors are thankful to M/s. Aurobindo Pharma Limited, Hyderabad for providing gift samples of lamivudine, zidovudine, abacavir and stavudine.

\section{References}

1. Sweetman S C, Martindale, The Complete Drug Reference, $33^{\text {rd }}$ Ed., London, Pharmaceutical Press, 2002.

2. Montvale, N J, Physician's Desk Reference, $56^{\text {th }}$ Ed., Montvale, Medical Economics Company Inc, 2003.

3. Indian Pharmacopoiea 1996 (Addendum 2002), Govt. of India, Ministry of Health and Family Welfare. Delhi, Controller of Publications, 2002.

4. Uslu B and Ozkan S, Anal Chem Acta, 2002, 59,175-182.

5. Moore J D, Valette G, Darque A, Zhou X J and Sommadassi J P, J Am Soc Mass Spectrom., 2000, 11,1134.

6. Kenney K B, Wring S A, Carr R M, Well GN and Dunn J A, J Pharm Biomed Anal., 2000, 22, 967.

7. Savaser A, Goraler S, Tasoz A, Uslu B, Lingeman H, and Ozkan S A. Chromatographia, 2007, 65,259. 


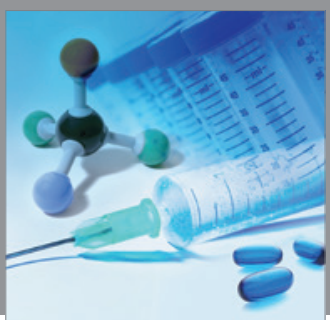

International Journal of

Medicinal Chemistry

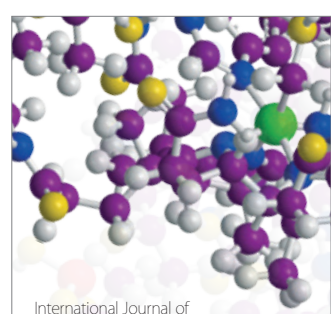

Carbohydrate Chemistry

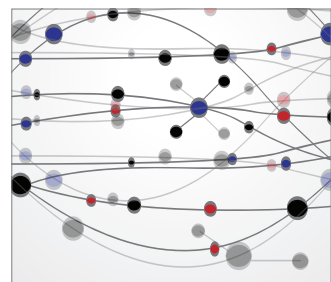

The Scientific World Journal
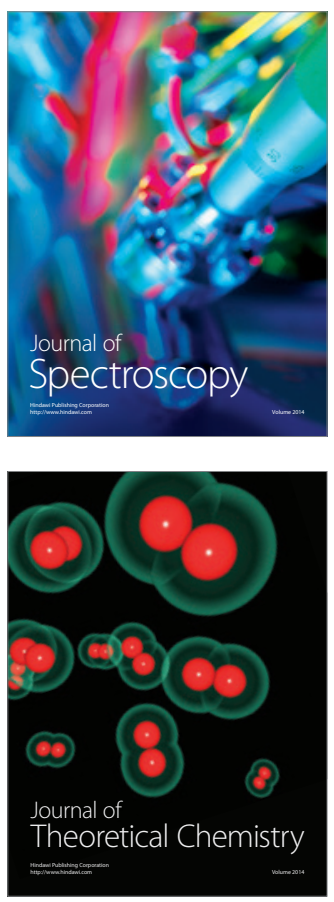
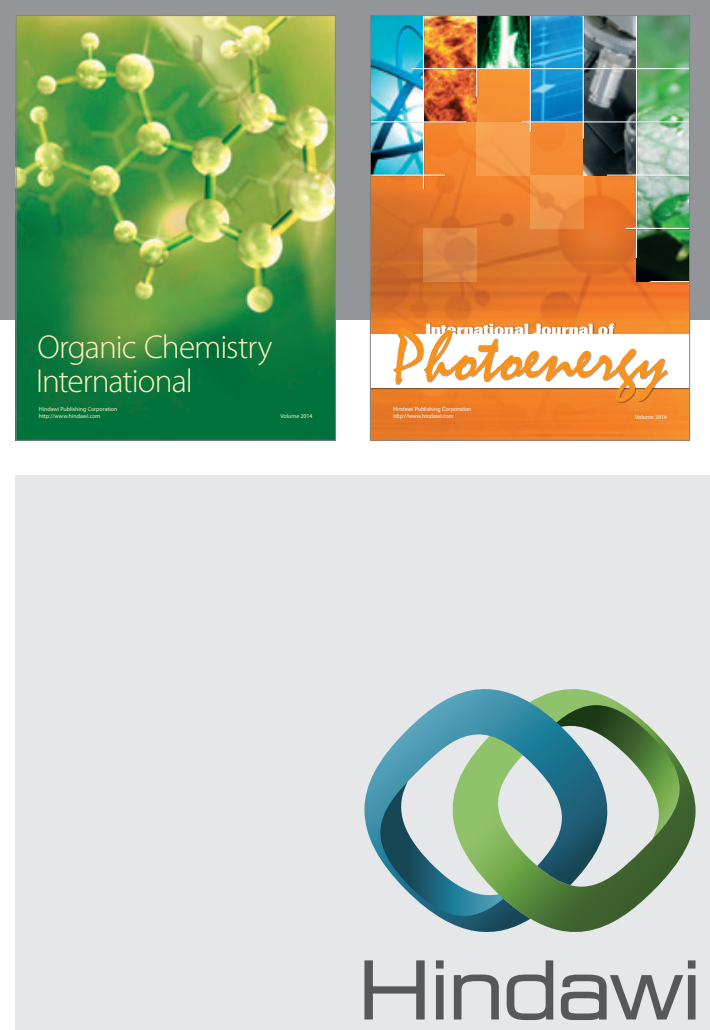

Submit your manuscripts at

http://www.hindawi.com
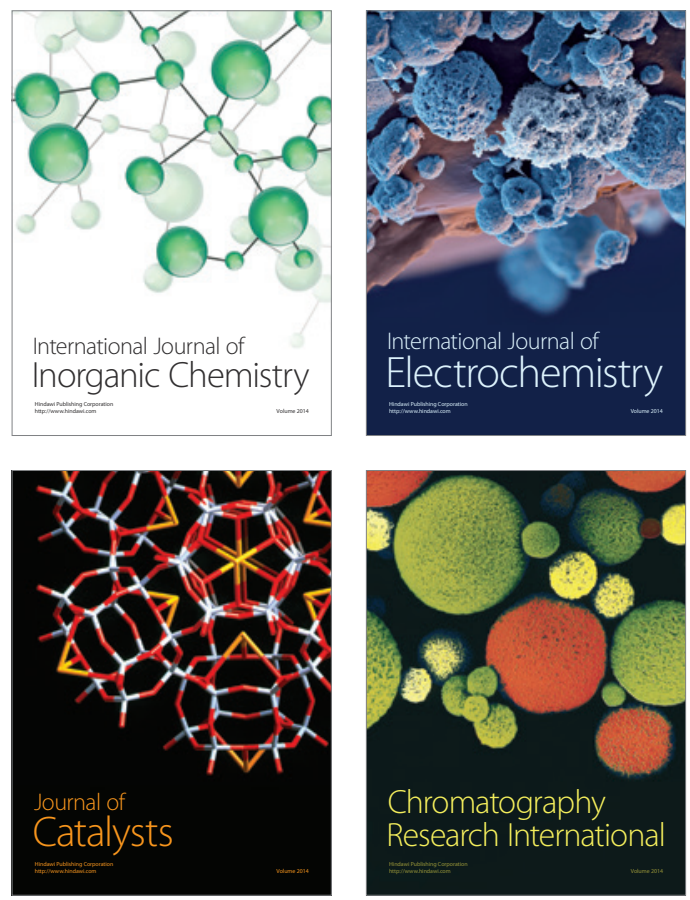
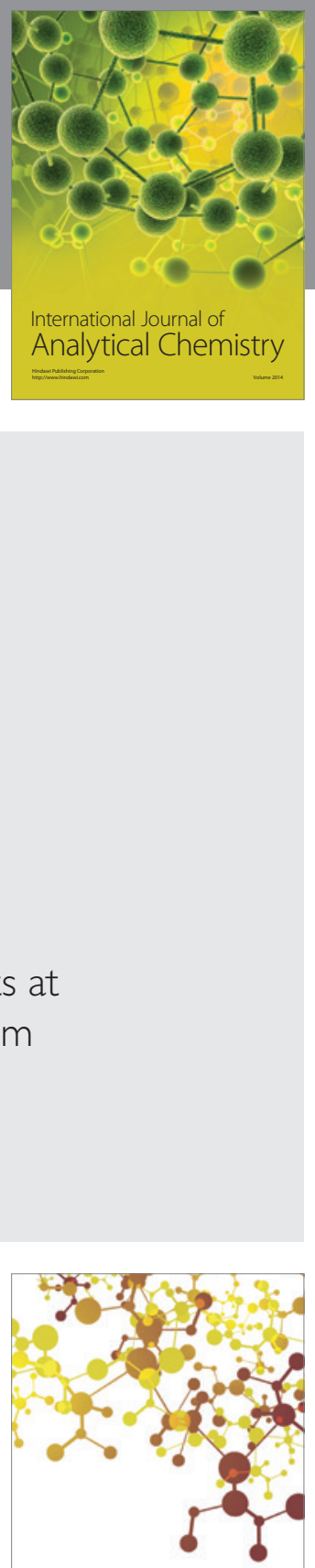

Journal of

Applied Chemistry
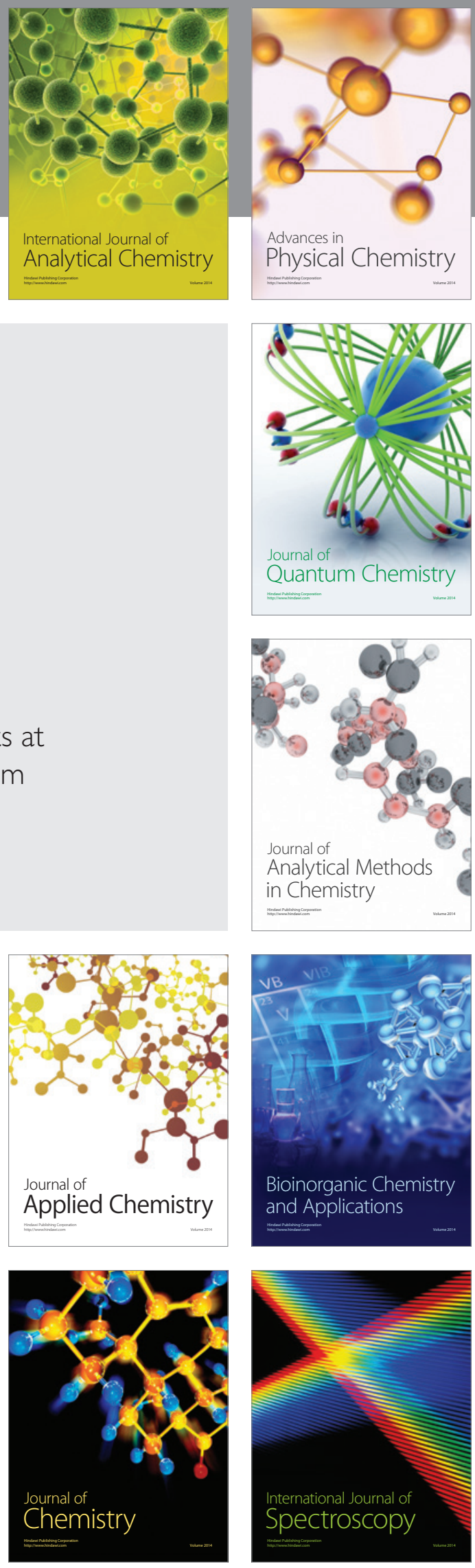